\title{
Evaluating the Effects of Cellulolytic Enzymes and Lactobacillus bulgaricus on Mycotoxins Production and the Quality of Maize Silage
}

\author{
Marwah M. Bakri
}

Fungal spoilage and mycotoxin contamination are two of the greatest hazards of silage. The present work was carried out to evaluate the impact of Lactobacillus bulgaricus and cellulolytic enzymes on the maize silage (MS) quality. Fungal analysis of different MS samples showed different mycotoxigenic fungi. The highest frequency $(62.8 \%)$ was associated with Fusarium spp. Four species with different relative densities were found: $F$. graminearum $(71.1 \%)$, F. culmorum $(15.2 \%)$, F. proliferatum $(11.2 \%)$, and F. oxysporum $(2.50 \%)$. High-performance liquid chromatography analysis showed the presence of trichothecene, nivalenol, zearalenone, and fumonisins mycotoxins in MS inoculated by $F$. graminearum. The inhibition $\%$ of trichothecene, nivalenol, and zearalenone synthesis was $50.2 \%$, $47.5 \%$, and $23.5 \%$, respectively, in MS inoculated by Lactobacillus bulgaricus after a $30 \mathrm{~d}$ incubation period. Trichoderma harzianum succeeded in producing cellulolytic enzymes, i.e., carboxymethyl cellulase, manganase peroxidase, and laccase, with a maximum production of $350 \mu \mathrm{g} / \mathrm{mL}, 5.47 \mu \mathrm{g} / \mathrm{mL}$, and $16.0 \mu \mathrm{g} / \mathrm{mL}$, respectively, after $21 \mathrm{~d}$ using MS as the substrate. Treatment by the extracted cellulolytic enzyme with $L$. bulgaricus enhanced unfavorable conditions for MS fungal contamination, i.e., the production of lactic acid, a lowered $\mathrm{pH}$, and increased $L$. bulgaricus colony-forming units, compared to the addition of enzyme extract or L. bulgaricus alone.

Keywords: Cellulolytic enzymes; Maize silage; Lactobacillus bulgaricus; Mycotoxins

Contact information: University College, Al-Ardah, Jazan University (45142), Jazan, Saudi Arabia;

* Corresponding author: marwah890@gmail.com

\section{INTRODUCTION}

In the last decade, silage production has attracted the attention of most of the livestock farmers in the world due to its high nutritional protein and carbohydrate values. Silage production depends on the fermentation of a chopped fresh crops, e.g., maize, wheat, and rice, followed by storing the prepared silage in the absence of oxygen. Corn silage has become one of the most important food sources for most animals, especially cows and buffaloes, as it was found to increase the amount of meat as well as increase milk productivity (Khatun et al. 2016; Miller et al. 2020). Certain requirements are essential for silage production in order to avoid its spoilage via harmful and toxin-producing microbes, e.g., anaerobic conditions are important for silage preservation. However, these conditions also promote the proliferation of lactic acid bacteria. Anaerobiosis and a lower $\mathrm{pH}$ represent an unfavorable habitat for mold proliferation (Motta et al. 2020).

Mold growth appears if these conditions are disrupted, particularly after starting to use the corn silage. Whitlow and Hagler (2005) mentioned that the fungi can colonize the silage if oxygen is available. Other environmental conditions, e.g., a high temperature and 
humidity, increase the chance of fungi spreading during silage storage (Egal et al. 2005; Richard et al. 2007; Ogunade et al. 2018). Often, the existence of fungi in the silage can be attributed to the colonization of corn in the field or throughout silage storage. However, not only the presence of fungi, but also the presence of mycotoxins, are considered potential threat factors for animals and humans during the daily handling of spoiled silage. Unfortunately, scientific studies have primarily concentrated on the occurrence of mycotoxins in cereal crops, which is likely due to the fact that they are consumed in larger amounts by humans compared to other feed types (Bhat et al. 2010). However, numerous mycotoxins have been detected in a range of livestock feed comprising silages (Keller et al. 2013). Incidents of mycotoxins in silage were recorded by O'Brien et al. (2008) and Cheli et al. (2013); therefore, Wambacq et al. (2016) stated that proper silage management is important to minimize mycotoxin contamination of dairy animal feeds through the use of chemical additives or microbial inoculants that can reduce the spoiled levels. Many Fusarium mycotoxins were discovered in silages, e.g., moniliformin, enniatins (ENN), beauvericins, and fusaric acid; another Fusarium mycotoxin, deoxynivalenol (DON), was found in $86 \%$ of the collected corn silage samples (McElhinney et al. 2015; Kosicki et al. 2016). Previously, Eckard et al. (2011) reported that maize silage was a good reservoir for Fusarium spp. growth and its mycotoxins included numerous trichothecenes, e.g., fusarenon X, diacetoxyscirpenol, nivalenol (NIV), and acetylated DON. Recently, NIV and DON were the most widespread mycotoxins, being found in $97.7 \%$ of the collected maize silages samples, followed by ENN B (Vandicke et al. 2021). The phenomenon of the spread of fungi and mycotoxins in maize silage deserves more attention than currently given, due to the seriousness of the situation. This can be addressed by following the correct methods of making silage or by adding additives that limit the presence of fungi. Bioadditives, e.g., lactic acid bacteria, were documented to improve the quality of silage and prevent mold growth (Xu et al. 2017). Improving the aerobic stability of silages was observed via the addition of Lactobacillus buchneri, through its conversion of lactic acid to acetic acid (Li et al. 2016). Recently, Selwet (2020) studied the addition of different Lactobacillus strains on the quality of maize silage. Remarkable increases in concentration of lactic acid, acetic acid and propionic acid were observed, in addition to extended the silage aerobic stability. These acids rapidly acidify silage, thereby repressing the undesirable bacteria growth. Furthermore, acetic and propionic acids serve as fungi-static agents.

Lactobacillus plantarum and Pediococcus acidilactici, in conjunction with amylase enzyme, enhanced the fermentation characteristics and aerobic stability of maize silages by promoting bacterial production of volatile fatty acids, e.g., acetic and propionic acids, which repress molds growth (Koc et al. 2008). Additional additives, e.g., hydrolytic enzymes, are used extensively in silage production; these enzymes have the ability to release monosaccharaides via the degradation of plant cell walls (Muck et al. 2018). According to Silva et al. (2016) enzyme preparations can be applied as mentioned in silage production, but they are highly expensive and it is more problematic to formulate them. Therefore, a search for alternative economical source such as microbial producing enzymes is needed. An increase in lactate levels and a reduction in ammonia-N levels were observed by Shepherd and Kung (1996) in silage treated with hydrolytic enzymes, e.g., amylase, cellulase, and pectinase. Recently, a combination of lactic acid bacteria and fibrolytic enzymes, e.g., cellulose and hemicellulose, was applied to improve the nutritional availability of silage (Hu et al. 2021). Therefore, more data on maize silage is needed to avoid fungal contamination and mycotoxin production by using safe bacterial inoculants, which represents the aim of this study. 


\section{EXPERIMENTAL}

\section{Collection of Maize Silage for Fungal Analysis}

Nine maize silage samples (Zea mays L.) were taken from a silo at the top, center, and bottom (three samples for each position) after $40 \mathrm{~d}$ of production; the level of each sample was approximately $20 \mathrm{~cm}$ in length and $20 \mathrm{~cm}$ in width. Then, $500 \mathrm{~g}$ of each sample were mixed with a homogenizer to get a homogeneous sample under aseptic conditions (To avoid contamination from other sources such as air, dust, etc.) for fungal analysis. Next, $50 \mathrm{~g}$ of each sample was shaken for $30 \mathrm{~min}$ in $250 \mathrm{~mL}$ of sterile water containing $0.15 \mathrm{~g}$ of sodium dodecyl sulfate. In a plastic petri plate containing malt extract agar medium supplemented with chloramphenicol $(0.05 \%, \mathrm{w} / \mathrm{v}), 1 \mathrm{~mL}$ of each suspension was sprayed onto the surface of the medium, followed by incubation at a temperature of $28{ }^{\circ} \mathrm{C}$ for $6 \mathrm{~d}$. The fungal colonies that appeared were purified and identified. The identification was based on macroscopical and microscopical characterization (Raper and Fennell 1973; Domsch et al. 1980; Klich 2002). The isolate frequency (Fr) and relative density (RD) of the species were calculated according to Eq. 1 and Eq. 2, respectively,

$$
\begin{aligned}
& \text { Fr }(\%)=\frac{\text { Number of samples with a species or genus }}{\text { Total number of samples }} \times 100 \\
& \operatorname{RD}(\%)=\frac{\text { Number of isolates of species or genus }}{\text { Total number of isolated fungi in samples }} \times 100
\end{aligned}
$$

as outlined in Gonzalez et al. (1995).

\section{Effect of Lactobacillus bulgaricus on Mycotoxins Production by Fusarium graminearum}

Freshly prepared maize silage $(50 \mathrm{~g})$, from the same samples used for the fungal analysis, was moistened in a $250 \mathrm{~mL}$ conical flask using $100 \mathrm{~mL}$ of distilled water, followed by autoclaving for $30 \mathrm{~min}$ at a temperature of $121{ }^{\circ} \mathrm{C}$. Two discs ( $1 \mathrm{~mm}$ radius) from the active margin of a $F$. graminearum colony (species with the highest $\mathrm{RD}$ ) growing on potato dextrose agar medium and $2 \mathrm{~mL}$ of a $L$. bulgaricus (obtained from the researchers in El-Taher et al. (2012) suspension were inoculated in the silage followed by incubation at a temperature of $30^{\circ} \mathrm{C}$ for up to $30 \mathrm{~d}$. At the end of the incubation period, a filtrate of the metabolized medium was extracted via chloroform and methanol (a 2 to 1 ratio) for mycotoxins analysis via high-performance liquid chromatography (HPLC). (Series 1100,

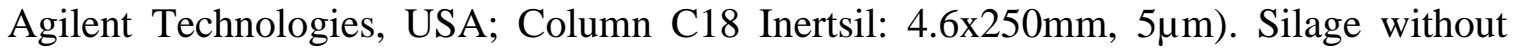
inoculation by $F$. graminearum was used as a control with $15 \mathrm{~d}$ and $30 \mathrm{~d}$ of incubation.

\section{Enzyme Preparation}

Freshly prepared maize silage $(10 \mathrm{~g})$, from the same samples used for the fungal analysis, was moistened in a $250 \mathrm{~mL}$ conical flask using $20 \mathrm{~mL}$ of distilled water, followed by autoclaving for $30 \mathrm{~min}$ at a temperature of $121{ }^{\circ} \mathrm{C}$. Two discs ( $1 \mathrm{~mm}$ radius) from the active margin of a Trichoderma harzianum (from the Regional Center of Mycology and Biotechnology, Al-Azhar University, Cairo, Egypt) colony growing on Czapek dox agar medium were inoculated in the silage and incubated at a temperature of $30{ }^{\circ} \mathrm{C}$ for different incubation periods, up to $28 \mathrm{~d}$. At the end of the incubation period, $50 \mathrm{~mL}$ of distilled water was added to the substrate and agitated via shaking (at $500 \mathrm{rpm}$ ) for $25 \mathrm{~min}$, then clarified via muslin cloth, and then centrifuged for $5 \mathrm{~min}$ at $10 \times 10^{3} \mathrm{rpm}$ for further filtration. The supernatant containing the enzymes was collected and used as crude enzymes for assaying 
its carboxymethyl cellulase (CMCase), manganase peroxidase (MnPase), laccase, and soluble protein contents.

\section{Carboxymethyl Cellulase, Manganase Peroxidase, and Laccase Assay}

The CMCase activity was determined by a reaction mixture containing $1.0 \mathrm{~g}$ of carboxymethyl cellulose (CMC) as an enzyme substrate in $100 \mathrm{~mL}$ of sodium acetate buffer (with a $\mathrm{pH}$ of 5.0). Then, $1 \mathrm{~mL}$ of the supernatant containing enzymes was tested to break down the enzyme substrate in a tube containing the reaction mixture, then incubated for 30 min at a temperature of $63{ }^{\circ} \mathrm{C}$. The amount of liberated reducing sugars was calculated using a spectrophotometer at $540 \mathrm{~nm}$ via the 3,5-dinitrosalicylic acid (DNS) protocol regarding to the standard curve of glucose, by reading the absorbance at $540 \mathrm{~nm}$ (Miller 1959). The analysis found that 1 unit of CMCase is the micromoles of glucose liberated per $1 \mathrm{~mL}$ of supernatant containing enzyme per min (Wang et al. 1988). The reaction mixture for determining the MnPase activity, according to Garzillo et al. (2001), included $100 \mu \mathrm{L}$ of the supernatant containing enzyme, $1 \mathrm{mM}$ of $\mathrm{MnSO}_{4}$ in a Mcllvaine buffer (with a pH of 5.0), and $2 \mathrm{mM}$ of 2,2'-azino-bis(3-ethyl benzo-thiazoline-6-sulforic acid) (ABTS) $(1 \mathrm{~mL})$, followed by the addition of $4 \mathrm{mM}$ of $\mathrm{H}_{2} \mathrm{O}_{2}$ as a substrate for peroxidase activity in the reaction mixture. The MnPase activity was determined in IU by checking the spectrophotometer absorbance change at $420 \mathrm{~nm}$ (ABTS), $\epsilon=36 \mathrm{Mm}^{-1} \mathrm{~cm}^{-1}$. For the laccase assay, the reaction mixture comprised of $100 \mu \mathrm{L}$ of the supernatant containing enzyme and $2 \mathrm{mM}$ of ABTS ( $1 \mathrm{~mL})$ adjusted to a $\mathrm{pH}$ of 5 using Mcllvaine buffer. The activity of the enzyme was recorded in IU via a spectrophotometer at $420 \mathrm{~nm}$ (ABTS), $C$ $=36 \mathrm{Mm}^{-1} \mathrm{~cm}^{-1}$ (Garzillo et al. 2001). Distilled water was used instead of the enzymes for the blank sample.

\section{Protein and Reducing Sugar Assays}

First, $1 \mathrm{~mL}$ of DNS reagent was added to $1 \mathrm{~mL}$ of sugar solution in a tube, followed by placing it in a boiling water bath for $10 \mathrm{~min}$. After cooling the tube containing the reaction mixture to $30{ }^{\circ} \mathrm{C}, 5 \mathrm{~mL}$ of distilled water was added. The developed color was analyzed via a spectrophotometer at $540 \mathrm{~nm}$, with glucose being used as the standard (Miller 1959). Assessing the total soluble protein in the supernatant was achieved according to the methodology outlined in Lowry et al. (1951). The blank sample was recorded using $1 \mathrm{~mL}$ of distilled water.

\section{Effect of Enzymes Extract and Lactobacillus bulgaricus on Chemical Characteristics of Silage}

Freshly prepared maize silage (50 g), from the same samples used for the fungal analysis, was moistened in a $250 \mathrm{~mL}$ conical flask using $100 \mathrm{~mL}$ of distilled water, followed by autoclaving for $30 \mathrm{~min}$ at a temperature of $121^{\circ} \mathrm{C}$. Then, $2 \mathrm{~mL}$ of the $L$. bulgaricus suspension and enzyme extract from the previous enzyme production experiment at optimal conditions were added to the silage, followed by incubation at a temperature of $30^{\circ} \mathrm{C}$ for up to $30 \mathrm{~d}$. At the end of the incubation period, the filtrate of the metabolized medium was extracted to determine the lactic acid content via HPLC. In addition, the dry and organic matter content, $\mathrm{pH}$, and the number of L. bulgaricus cells were determined. 


\section{Statistical Analysis}

The standard deviation mean $( \pm$ SD) of the three readings of obtained results was calculated using SPSS software (version 22.0, IBM, Armonk, NY).

\section{RESULTS AND DISCUSSION}

\section{Fungal Identification of the Contaminated Maize Silage}

Fungal spoilage was observed in the maize silage samples after $60 \mathrm{~d}$ of production (Fig. 1).
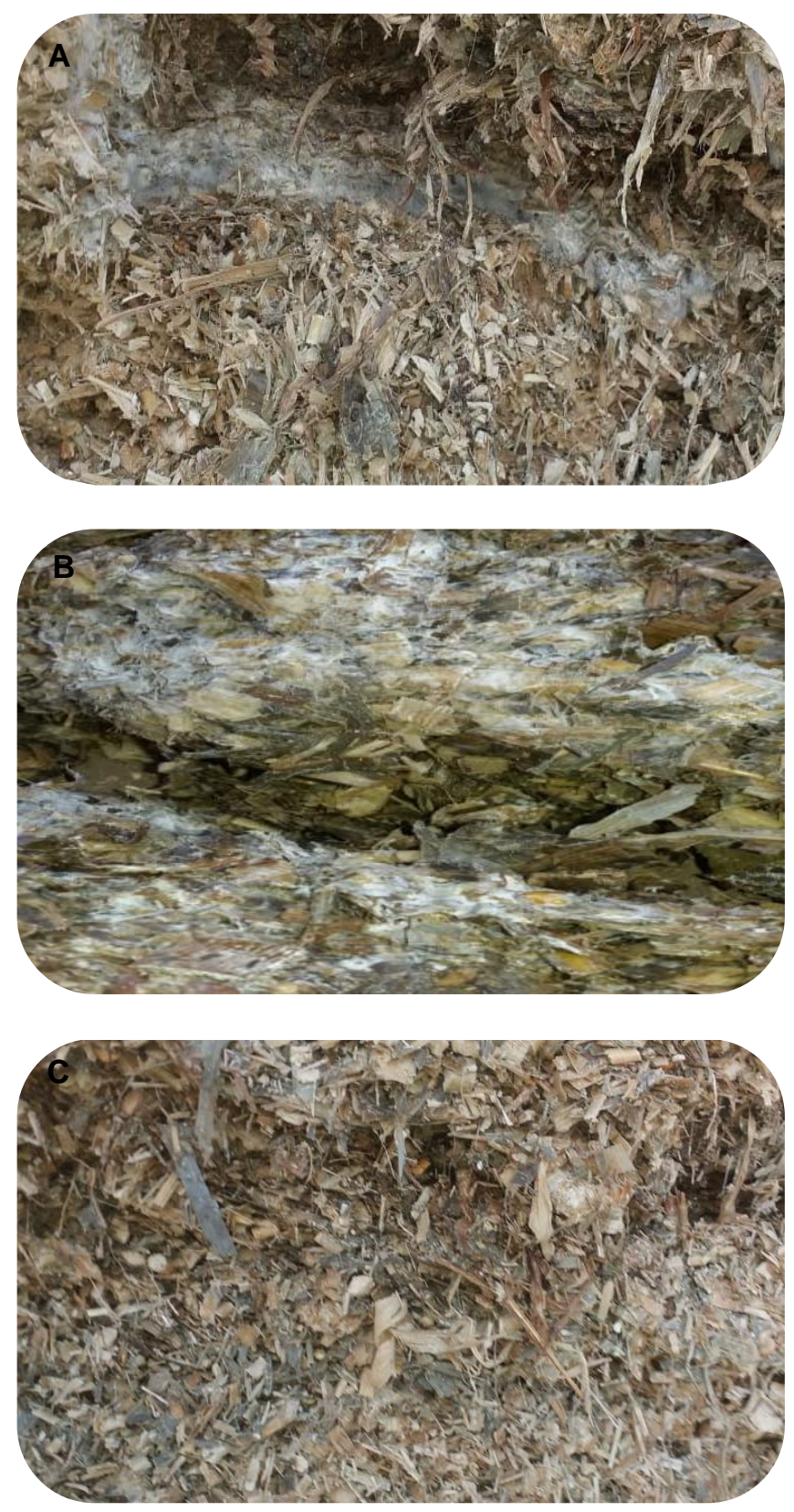

Fig. 1. Typical mold growth in dry silage 
The identification methods confirmed the presence of five filamentous toxigenic fungi, i.e., Aspergillus spp., Fusarium spp., Mucor spp., Rhizopus spp., and Penicillium spp., which all had different Fr values (Fig. 2). Fusarium spp. was identified with the highest Fr (62.8\%), followed by Aspergillus spp., with Mucor spp. having the lowest Fr $(10.2 \%)$. The presence of mycobiota in the maize silage was comparable to the species present in the same type of silage used in many countries, since Fusarium was found to be the primary isolate. In addition, in the Netherlands, Asselt et al. (2012) recorded an elevated incidence of Fusarium species and their mycotoxins in maize silage. However, Keller et al. (2013) demonstrated that Aspergillus, followed by Penicillium, were the most frequently isolated genera. A report by O'Brien et al. (2008) showed the presence of Penicillium spp. as a major contaminant in various types of silages. The presence of different fungi is considered unattractive in maize silage, as this suggests a high likelihood that the silage may be contaminated with numerous mycotoxins.

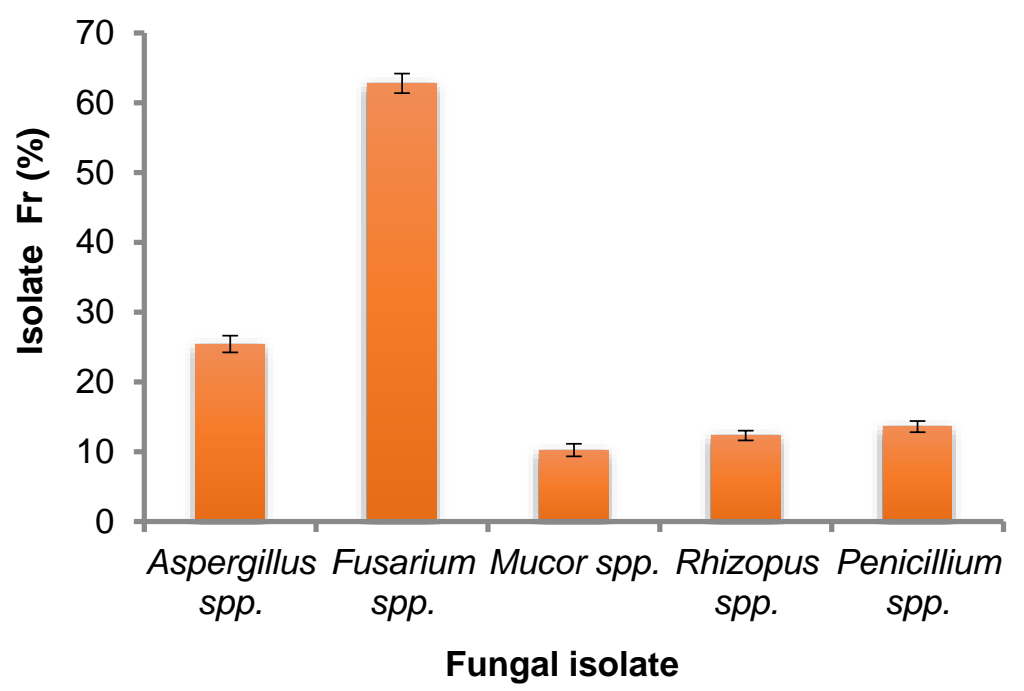

Fig. 2. Isolate Fr of the fungal isolates from maize silage (Note: the error bars referred to the SD of the three treatment values)

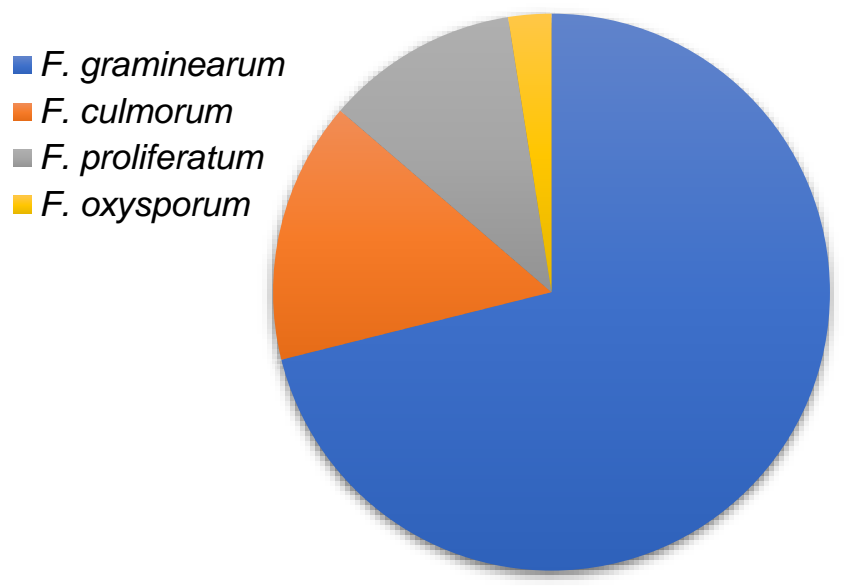

Fig. 3. RD (\%) of the Fusarium species isolated from the maize silage samples 
The highest occurrence of fungal isolates was observed at the upper and lower sections (Fig. 1A and 1B), while the middle section showed a lower level of fungal contamination (Fig. 1C). Fungal analysis of the highest Fr. isolate (Fusarium spp.) indicated the presence of four species with different RD values, i.e., F. graminearum $(71.1$ $\%), F$. culmorum (15.2\%), F. proliferatum (11.2\%), and $F$. oxysporum $(2.50 \%)$. The species with the highest RD value ( $F$. graminearum) was used for further study (Fig. 3 ).

\section{Mycotoxin production}

Four mycotoxins, i.e., trichothecene, nivalenol, zearalenone, and fumonisins, were produced by $F$. graminearum using maize silage as a substrate (as shown in Table 1 and Fig. 4). These mycotoxins were found to be $F$. graminearum metabolites by Tralamazza $e t$ al. (2016). As mentioned by Wu et al. (2017), Fusarium mycotoxins are considered the most common toxin in crops globally. The synthesis of mycotoxins is a complicated metabolic pathway that is regulated by genetic factors, which can be affected via several environmental and nutritional stimuli, e.g., temperature, $\mathrm{pH}$, nutrient composition, and the availability of substrates (Abdel-Ghany 2008; Xue et al. 2014). The obtained results reflected the effect of $L$. bulgaricus on $F$. graminearum mycotoxins production in maize silage after 15 and $30 \mathrm{~d}$ of incubation (as shown in Table 1). The production of trichothecene and nivalenol were more affected by the addition of L. bulgaricus, particularly after $30 \mathrm{~d}$ of incubation, while zearalenone production was less affected. Unfortunately, fumonisins productivity increased as a result of the addition of $L$. bulgaricus. The inhibition \% of trichothecene, nivalenol, and zearalenone synthesis, regarding the control at $30 \mathrm{~d}$, reached $50.24 \%, 47.50 \%$, and $23.54 \%$, respectively, while at $15 \mathrm{~d}$ reached $24.58 \%, 19.92 \%$, and $2.68 \%$, respectively. The $\mathrm{pH}$ was considered the critical factor for regulating the synthesis of mycotoxins outside of improving the silage quality. The lowering of the $\mathrm{pH}$ of the silage was due to the production of lactic acid in the silage. As such, a sharp decrease in the $\mathrm{pH}$ of the maize silage treated with lactic acid bacteria was observed, which was accompanied by organic acids production (Santos et al. 2019).

Table 1. Mycotoxin Production by F. graminearum Using Different Treatments

\begin{tabular}{|c|c|c|c|c|}
\hline \multirow{2}{*}{ Treatment } & \multicolumn{4}{|c|}{ Mycotoxin Concentration $(\mu \mathrm{g} / \mathrm{mL})$} \\
\cline { 2 - 5 } & Trichothecene & Nivalenol & Zearalenone & Fumonisins \\
\hline Control (30 d) & $60.79 \pm 0.02$ & $51.21 \pm 0.02$ & $32.94 \pm 0.351$ & $16.15 \pm 0.05$ \\
\hline Control (15 d) & $40.24 \pm 0.01$ & $44.27 \pm 0.12$ & $29.84 \pm 0.01$ & $17.49 \pm 0.20$ \\
\hline L. bulgaricus (15 d) & $30.35 \pm 0.02$ & $35.45 \pm 0.33$ & $29.04 \pm 0.05$ & $28.98 \pm 0.05$ \\
\hline L. bulgaricus (30 d) & $30.25 \pm 0.33$ & $26.89 \pm 0.02$ & $22.22 \pm 0.02$ & $20.15 \pm 0.02$ \\
\hline${ }^{*} \%$ Control/ L. bulgaricus at 30 d & 50.24 & 47.50 & 23.54 & 00.00 \\
\hline${ }^{*} \%$ Control/ L. bulgaricus at 15 d & 24.58 & 19.92 & 2.68 & 00.00 \\
\hline Retention time & 6.01 & 7.30 & 8.60 & 8.80 \\
\hline & & & & \\
\hline
\end{tabular}

Note: *I is the inhibition \% of mycotoxins via the L. bulgaricus treatment with regards to the control 

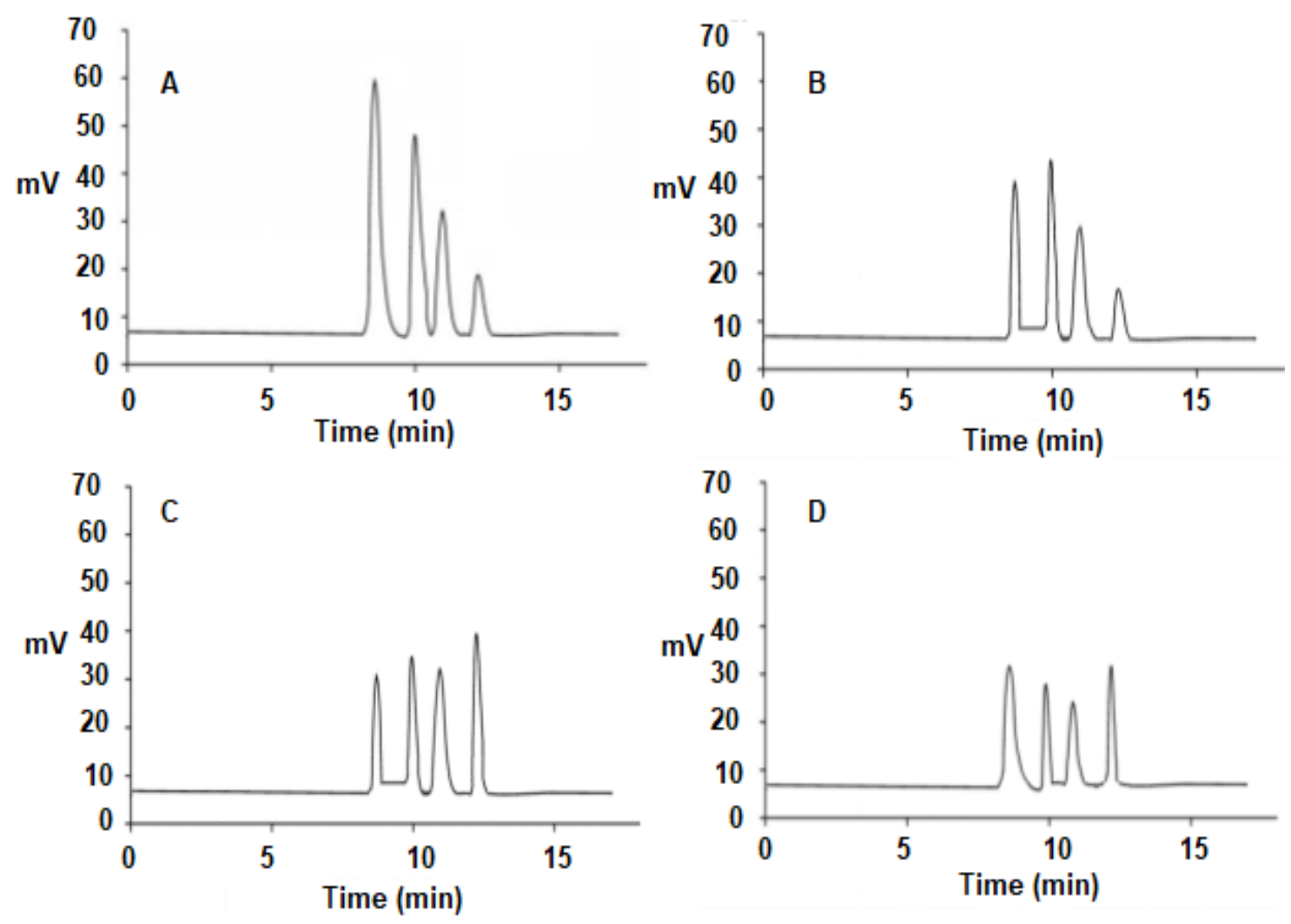

Fig. 4. The HPLC chromatogram of mycotoxin production by $F$. graminearum for different treatments: A) control (30 d); B) control (15 d); C) L. bulgaricus (15 d); and D) L. bulgaricus (30 d)

\section{Enzyme production}

Due to the richness of the maize silage with lignocellulolytic compounds, in addition to other nutritional compounds, the production of cellulolytic enzymes by $T$. harzianum using maize silage increased as the incubation period increased, up to $21 \mathrm{~d}$ (accompanied by increased protein liberation), but it decreased after $28 \mathrm{~d}$ (as shown in Table 2). The maximum productivity of CMCase, manganase peroxidase, and laccase was reached after $21 \mathrm{~d}$, i.e., $350.50 \mu \mathrm{g} / \mathrm{mL}, 5.47 \mu \mathrm{g} / \mathrm{mL}$, and $16.04 \mu \mathrm{g} / \mathrm{mL}$, respectively. In addition to the biosafety of $T$. harzianum, its ability to produce multiple cellulolytic enzymes using different agricultural residues has been recognized and documented and it is often chosen as a good enzyme producer (Lee et al. 2017; Abdel-Ghany and Bakri 2019; Asis et al. 2021).

Table 2. Enzyme Production by Trichoderma harzianum Using Maize Silage

\begin{tabular}{|c|c|c|c|c|}
\hline \multirow{2}{*}{$\begin{array}{c}\text { Incubation } \\
\text { Period } \\
\text { (Day) }\end{array}$} & \multicolumn{3}{|c|}{ Enzyme Activity $(\mu \mathrm{g} / \mathrm{mL})$} & \multirow{2}{*}{$\begin{array}{c}\text { Protein } \\
(\mu \mathrm{g} / \mathrm{mL})\end{array}$} \\
\cline { 2 - 5 } & Carboxymethyl cellulase & Manganase peroxidase & Laccase & \\
\hline 7 & $55.23 \pm 0.58$ & $2.52 \pm 0.01$ & $12.94 \pm 0.13$ & $400 \pm 0.76$ \\
\hline 14 & $200.43 \pm 1.53$ & $4.34 \pm 0.02$ & $15.84 \pm 0.06$ & $470 \pm 0.50$ \\
\hline 21 & $350.50 \pm 1.15$ & $5.47 \pm 0.29$ & $16.04 \pm 0.58$ & $600 \pm 0.29$ \\
\hline 28 & $300.35 \pm 0.02$ & $4.61 \pm 0.04$ & $15.22 \pm 0.58$ & $578 \pm 1.53$ \\
\hline
\end{tabular}


The role of $L$. bulgaricus and enzyme extract

Cellulolytic enzymes play a vital role in numerous industrial applications, and in the current study, cellulolytic enzymes were applied in order to enhance conditions that prevented the growth of undesirable fungi and their mycotoxins in maize silage indirectly through encouraging the proliferation of L. bulgaricus (Ganash et al. 2021). Li et al. (2020) mentioned that some lactic acid bacteria (LAB) might be able to minimize the lignin content in silage when amended with cellulase enzyme. The addition of extract containing a high amount of enzyme (after $21 \mathrm{~d}$ of incubation) to maize silage inoculated with $L$. bulgaricus increased the growth of L. bulgaricus, as well as increased the dry matter (DM) and organic matter (OM) contents, and the lactic acid production, when compared to the untreated silage or the silage inoculated with only enzymes or L. bulgaricus (Table 3), as well as lowering the $\mathrm{pH}$. Recently, the enhancement of maize silage quality using microbial diversity and rumen degradation proportions were found via the addition of Lactobacillus and cellulase (Hu et al. 2021; Zhao et al. 2021). According to Khota et al. (2017), LAB are incapable of directly decaying lignocellulolytic residues of plants. Therefore, it is necessary to add other microbes that are able to break down lignins during the production of silage. Moreover, Kaewpila et al. (2021) found that cellulases or T. harzianum attractive inoculates enhanced the ensiling features of maize silage. In addition, lactic acid production increased when a mixture of enzyme extract and L. bulgaricus was added (Table 3), which demonstrated that the combined enzyme and L. bulgaricus treatment may be more effective compared to the enzyme extract treatment alone; these results were in agreement with a previous study by Li et al. (2018). The obtained results were recorded recently in alfalfa silage, since the LAB amplified the enzyme activity, thus accelerating the fermentation process and increasing lactic acid productivity (Hu et al. 2021). Further and coming studies is necessary to evaluate the other productivity of enzyme hydrolysis to silage components and its beneficial effects on consumers.

Table 3. Chemical and L. bulgaricus Analysis of Maize Silage Extracts After $40 \mathrm{~d}$ of Fermentation Treated by Crude Enzyme and L. bulgaricus

\begin{tabular}{|c|c|c|c|c|c|}
\hline Treatment & $\begin{array}{c}\text { L. bulgaricus } \\
\text { (log CFU/g) }\end{array}$ & $\mathrm{pH}$ & $\mathrm{DM}(\%)$ & $\mathrm{OM}(\%)$ & $\begin{array}{c}\text { Lactic Acid } \\
\text { (g/kg DM) }\end{array}$ \\
\hline Control $^{*}$ & $0.0 \pm 0.00$ & $4.9 \pm 0.02$ & $26.25 \pm 0.76$ & $71.56 \pm 0.2$ & $2.6 \pm 0.02$ \\
\hline L. bulgaricus $^{\text {L. bulgaricus + }}$ & $6.6 \pm 0.01$ & $4.6 \pm 0.03$ & $33.54 \pm 0.50$ & $79.11 \pm 0.62$ & $12.56 \pm 0.05$ \\
\hline Crude Enzyme $^{\star *}$ & $8.9 \pm 0.02$ & $4.4 \pm 0.06$ & $37.33 \pm 0.33$ & $88.06 \pm 0.2$ & $14.67 \pm 0.10$ \\
\hline Crude Enzyme $^{\star *}$ & $0.0 \pm 0.00$ & $4.8 \pm 0.01$ & $26.45 \pm 0.20$ & $72.12 \pm 0.25$ & $6.3 \pm 0.05$ \\
\hline
\end{tabular}

Control $^{*}$, Fresh maize silage un-treated with L. bulgaricus or Crude enzyme; Crude Enzyme ${ }^{\star *}$, Supernatant containing enzymes

\section{CONCLUSIONS}

1. Bioadditives, e.g., Lactobacillus bulgaricus, or lowering the $\mathrm{pH}$ through organic acids production, will help to support safe storage conditions and prevent mycotoxin production in maize silage. 
2. Proving the existence of multiple mycotoxigenic fungi was the highlight of this study; as such, the presence of various mycotoxins in the prepared maize silage was confirmed.

3. A combined enzyme extract and Lactobacillus bulgaricus treatment may be more valuable than either treatment alone, which provides suitable justification for its application in maize silage production.

\section{ACKNOWLEDGMENTS}

The author would like to give thanks to Jazan University for their support.

\section{REFERENCES CITED}

Abdel-Ghany, T. M. (2008). "Metabolic regulation of fungal reproduction and their secondary metabolites," Al-Azhar Bulletin of Science 17(1-C), 87-102.

DOI: $10.21608 / \mathrm{absb} .2006 .14728$

Abdel-Ghany, T. M., and Bakri, M. M. (2019). "Effectiveness of a biological agent (Trichoderma harzianum and its culture filtrate) and a fungicide (methyl benzimacold-2-ylcarbamate) on the tomato rotting activity (growth, cellulolytic, and pectinolytic activities) of Alternaria solani," BioResources 14(1), 1591-1602. DOI: 10.15376/biores.14.1.1591-1602

Asis, A., Shahriar, S. A., Naher, L., Suryani, S., Fatihah, H. N. N., Vijay, K., and Siddiquee, S. (2021). "Identification patterns of Trichoderma strains using morphological characteristics, phylogenetic analyses and lignocellulolytic activities," Molecular Biology Reports 48, 3285-3301. DOI: 10.1007/s11033-02106321-0

Asselt, E. D. v., Booij, C. J. H., and Fels-Klerx, H. J. v. d. (2012). "Modelling mycotoxin formation by Fusarium graminearum in maize in The Netherlands," Food Additives \& Contaminants: Part A 29(10), 1572-1580. DOI: 10.1080/19440049.2012.688877

Cheli, F., Campagnoli, A., and Dell'Orto V. (2013). "Fungal populations and mycotoxins in silages: From occurrence to analysis," Animal Feed Science and Technology 183(1-2), 1-16. DOI: 10.1016/j.anifeedsci.2013.01.013

Domsch, K. H., Grams, W., and Anderson, T.-H. (1980). Compendium of Soil Fungi, Academic Press, London, United Kingdom.

Eckard, S., Wettstein F. E., Forrer H.-R., and Vogelgsang, S. (2011). "Incidence of Fusarium species and mycotoxins in maize silage," Toxins 3(8), 949-967. DOI: 10.3390/toxins3080949

Egal, S., Hounsa, A., Gong, Y. Y., Turner, P. C., Wild, C. P., Hall, A. J., Hell, K., and Cardwell, K. F. (2005). "Dietary exposure to aflatoxin from maize and groundnut in young children from Benin and Togo, West Africa," Int. J. Food Microbiol. 104(2), 215-224. DOI: 10.1016/j.ijfoodmicro.2005.03.004

El-Taher, E. M., Abel-Ghany, T. M., Alawlaqi, M. M., and Ashour, M. S. (2012).

"Biosecurity for reducing ochratoxin A productivity and their impact on germination and ultrastructures of germinated wheat grains," Journal of Microbiology, Biotechnology and Food Science 2(1), 135-151. 
Ganash, M., Abdel-Ghany T. M., Abboud, M. A. A., Alawlaqi, M. M., Qanash, H., and Amin, B. H. (2021). "Lignocellulolytic activity of Pleurotus ostreatus under solid state fermentation using silage, stover, and cobs of maize," BioResources 16(2), 3797-3807. DOI: 10.15376/biores.16.2.3797-3807

Garzillo, A. M., Colao, M. C., Buonocore, V., Oliva, R., Falcigno, L., Saviano, M., Santoro, A. M., Zappala, R., Bonomo, R. P., Bianco, C., Giardina, P., Palmieri, G., and Sannia, G. (2001). "Structural and kinetic characterization of native laccases from Pleurotus ostreatus, Rigidoporus lignosus, and Trametes trogii," Journal of Protein Chemistry 20(3), 191-201. DOI: 10.1023/A:1010954812955

González, H. H. L., Resnik, S. L., Boca, R. T., and Marasas, W. F. (1995). "Mycoflora of Argentinian corn harvested in the main production area in 1990," Mycopathologia 130(1), 29-36. DOI: 10.1007/BF01104346.

Hu, Z., Ma, D., Niu, H., Chang, J., Yu, J., Qing, T., and Li, S. (2021). "Enzyme additives influence bacterial communities of Medicago sativa silage as determined by Illumina sequencing," AMB Express 11, 1-11. DOI: 10.1186/s13568-020-01158-5

Kaewpila, C., Thip-uten, S., Cherdthong, A., and Khota, W. (2021). "Impact of cellulase and lactic acid bacteria inoculant to modify ensiling characteristics and in vitro digestibility of sweet corn stover and cassava pulp silage," Agriculture 11(1), 1-12. DOI: 10.3390/agriculture11010066

Keller, L. A. M., González Pereyra, M. L., Keller, K. M., Alonso, V. A., Oliveira, A. A., Almeida, T. X., Barbosa, T. S., Nunes, L. M. T., Cavaglieri, L. R., and Rosa, C. A. R. (2013). "Fungal and mycotoxins contamination in corn silage: Monitoring risk before and after fermentation," J. Stored Prod. Res. 52, 42-47. DOI:

10.1016/j.jspr.2012.09.001

Khatun, M. J., Islam, M. R., Khan, M. K., and Ebrahimi, M. (2016). "Effects of nitrogen on growth, fodder yield and silage of maize and jumbo fodder with cowpea as inter cropping," Forage Research 42(2), 82-89.

Khota, W., Pholsen, S., Higgs, D. and Cai, Y. (2017). "Fermentation quality and in vitro methane production of sorghum silage prepared with cellulase and lactic acid bacteria," Asian-Australasian Journal of Animal Sciences 30(11), 1568-1574. DOI: 10.5713/ajas.16.0502

Klich, M. A. (2002). Identification of Common Aspergillus Species, Centraalbureau voor Schimmelcultures, Utrecht, The Netherlands.

Koc, F., Coskuntuna, L., and Levent O. M. (2008). "The effect of bacteria+enzyme mixture silage inoculant on the fermentation characteristic, cell wall contents and aerobic stabilities of maize silage," Pakistan Journal of Nutrition 7(2), 222-226. DOI: 10.3923/pjn.2008.222.226

Kosicki, R., Błajet-Kosicka, A., Grajewski, J., and Twaruzek, M. (2016). "Multiannual mycotoxin survey in feed materials and feeding stuffs," Animal Feed Science and Technology 215, 165-180. DOI: 10.1016/j.anifeedsci.2016.03.012

Lee, H., Lee, Y. M., Heo, Y. M., Lee, J., and Kim, J-J. (2017). "Evaluation of cellulolytic enzyme production by indigenous fungi in Korea," Korean Journal of Environmental Biology 35(4), 648-653. DOI: 10.11626/KJEB.2017.35.4.648

Li, F., Ke, W., Ding, Z., Bai, J., Zhang, Y., Xu, D., Li, Z., and Guo, X. (2020). "Pretreatment of Pennisetum sinese silages with ferulic acid esterase-producing lactic acid bacteria and cellulase at two dry matter contents: Fermentation characteristics, carbohydrates composition and enzymatic saccharification," Bioresource Technology 295, 1-10. DOI: 10.1016/j.biortech.2019.122261 
Li, J., Yuan, X., Dong, Z., Mugabe, W., and Shao, T. (2018). "The effects of fibrolytic enzymes, cellulolytic fungi and bacteria on the fermentation characteristics, structural carbohydrates degradation, and enzymatic conversion yields of Pennisetum sinese silage," Bioresource Technology 264, 123-130. DOI: 10.1016/j.biortech.2018.05.059

Li, P., Bai, S., You, M., and Shen, Y. (2016). "Effects of maturity stage and lactic acid bacteria on the fermentation quality and aerobic stability of Siberian wildrye silage," Food Science \& Nutrition 4(5), 664-670. DOI: 10.1002/fsn3.312

Li, S., Hartman, G. L., Domier, L. L., and Boykin, D. (2008). “Quantification of Fusarium solani f. sp. glycines isolates in soybean roots by colony-forming unit assays and real-time quantitative PCR," Theoretical and Applied Genetics 117, 343352. DOI: $10.1007 / \mathrm{s} 00122-008-0779-2$

Lowry, O. H., Rosebrough, N. J., Farr, A. L., and Randall, R. J. (1951). "Protein measurement with folin phenol reagent," J. Biol. Chem. 193, 265-275.

McElhinney, C., Danaher, M., Elliot, C. T., and O'Kiely, P. (2015). "Mycotoxins in farm silages - A 2-year Irish national survey," Grass and Forage Science 71(2), 339-352. DOI: $10.1111 /$ gfs.12191

Miller, G. L. (1959). "Use of dinitrosalicylic acid reagent for determination of reducing sugar," Anal Chem. 31(3), 426-428. DOI: 10.1021/ac60147a030

Miller, M. D., Kokko, C., Ballard, C.S., Dann, H. M., Fustini, M., Palmonari, A., Formigoni, A., Cotanch, K. W., and Grant, R. J. (2020). "Influence of fiber degradability of corn silage in diets with lower and higher fiber content on lactational performance, nutrient digestibility, and ruminal characteristics in lactating Holstein cows," Journal of Dairy Science 104(2), 1728-1743. DOI: 10.3168/jds.2020-19088

Motta, A. C. V., Araujo, E. M., Broadley, M. R., Young, S. D., Barbosa, J. Z., Prior, S. A., and Schmidt, P. (2020). "Minerals and potentially toxic elements in corn silage from tropical and subtropical Brazil," Revista Brasileira de Zootecnia 49, 1-15. DOI: 10.37496/rbz4920190214

Muck, R. E., Nadeau, E. M. G., McAllister, T. A., Contreras-Govea, F. E., Santos, M. C., and Kung, J. L. (2018). "Silage review: Recent advances and future uses of silage additives," Journal of Dairy Science 101(5), 3980-4000. DOI: 10.3168/jds.201713839

O'Brien, M., Egan, D., O'kiely, P., Forristal, P. D., Doohan, F. M., and Fuller, H. T. (2008). "Morphological and molecular characterization of Penicillium roqueforti and P. paneum isolated from baled grass silage," Mycological Research 112(8), 921932. DOI: 10.1016/j.mycres.2008.01.023

Ogunade, I. M., Martinez-Tuppia, C., Queiroz, O. C. M., Jiang, Y., Drouin, P., Wu, F., Vyas, D., and Adesogan, A. T. (2018). "Silage review: Mycotoxins in silage: Occurrence, effects, prevention, and mitigation," Journal of Dairy Science 101(5), 4034-4059. DOI: 10.3168/jds.2017-13788

Raper, K. B., and Fennell, D. I. (1973). The Genus Aspergillus, Lippincott Williams \& Wilkins, Philadelphia, PA.

Richard, E., Heutte, N., Sage, L., Pottier, D., Bouchart, V., Lebailly, P., and Garon, D. (2007). "Toxigenic fungi and mycotoxins in mature corn silage," Food and Chemical Toxicology 45(12), 2420-2425. DOI: 10.1016/j.fct.2007.06.018

Santos, A. d. O. d., Ávila, C. L. d. S., Soares, C., Carvalho, B. F., Schwan, R. F., and Lima, N. (2019). "Lactic acid bacteria diversity in corn silage produced in Minas Gerais (Brazil)," Annals of Microbiology 69, 1445-1459. DOI: 10.1007/s13213-01901528-w 
Shepherd, A. C., and Kung, J. L. (1996). "Effects of an enzyme additive on composition of corn silage ensiled at various stages of maturity," Journal of Dairy Science 79(10), 1767-1773. DOI: 10.3168/jds.S0022-0302(96)76544-X

Silva, T. H., Takiya, C. S., Vendramini, T. H. A., de Jesus, E. F., Zanferari, F., and Rennó, F. P. (2016). "Effects of dietary fibrolytic enzymes on chewing time, ruminal fermentation, and performance of mid-lactating dairy cows," Anim. Feed Sci. Tech. 221, 35-43. DOI:10.1016/j.anifeedsci.2016.08.013

Selwet, M. (2020). "Influence of inoculation with Lactobacillus on fermentation, production of 1,2-propanediol and 1-propanol as well as Maize silage aerobic stability," Open Life Sciences 15, 373-378. DOI: 10.1515/biol-2020-0038

Tralamazza, S. M., Bemvenuti, R. H., Zorzete, P., Garcia, F. d. S., and Corrêa, B. (2016). "Fungal diversity and natural occurrence of deoxynivalenol and zearalenone in freshly harvested wheat grains from Brazil," Food Chemistry 196, 445-450. DOI: 10.1016/j.foodchem.2015.09.063

Vandicke, J., Visschere, K. D., Ameye, M., Croubels, S., Saeger, S. D., Audenaert, K., and Haesaert, G. (2021). "Multi-mycotoxin contamination of maize silages in Flanders, Belgium: Monitoring mycotoxin levels from seed to feed," Toxins 13(3), 122. DOI: $10.3390 /$ toxins 13030202

Wambacq, E., Vanhoutte, I., Audenaert, K., Gelder, L. D., and Haesaert, G. (2016). "Occurrence, prevention and remediation of toxigenic fungi and mycotoxins in silage: A review," Journal of the Science of Food and Agriculture 96(7), 2284-2302. DOI: $10.1002 /$ jsfa. 7565

Wang, C., Hseu, T., and Huang, C. (1988). "Induction of cellulose by cellooligosaccharides in Trichoderma konigii G-39," J. Biotechnol. 9, 47-60.

Whitlow, L. W., and Hagler, W. M. (2005). "Mycotoxins in feeds," Feedstuffs 76, 69-79. Wu, L., Qiu, L., Zhang, H., Sun, J., Hu, X., and Wang, B. (2017). "Optimization for the production of deoxynivalenol and zearalenone by Fusarium graminearum using response surface methodology," Toxins 9(2), 1-17. DOI: 10.3390/toxins9020057

$\mathrm{Xu}, \mathrm{Z}$., He, H., Zhang, S., and Kong, J. (2017). "Effects of inoculants Lactobacillus brevis and Lactobacillus parafarraginis on the fermentation characteristics and microbial communities of corn stover silage," Scientific Reports 7(1), 1-9. DOI: 10.1038/s41598-017-14052-1

Xue, H.-L., Bi, Y., Tang, Y.-M., Zhao, Y., and Wang, Y. (2014). "Effect of cultivars, Fusarium strains and storage temperature on trichothecenes production in inoculated potato tubers," Food Chemistry 151, 236-242.

DOI: 10.1016/j.foodchem.2013.11.060

Zhao, C., Wang, L., Ma, G., Jiang, X., Yang, J., Lv, J., and Zhang, Y. (2021). “Cellulase interacts with lactic acid bacteria to affect fermentation quality, microbial community, and ruminal degradability in mixed silage of soybean residue and corn stover," Animals 11(2), 1-15. DOI: 10.3390/ani11020334

Article submitted: August 10, 2021; Peer review completed: September 28, 2021;

Revised version received and accepted: October 20, 2021; Published: November 1, 2021. DOI: 10.15376/biores.16.4.8366-8378 